\title{
THE IDEA OF SIN IN TWENTIETH-CENTURY THEOLOGY
}

\author{
By BRUCE A. MILNE
}

\section{Introduction}

'The whole nature of the Christian religion stands upon these two great pillars, namely, the greatness of our fall and the greatness of our redemption.'1

So wrote William Law, thereby reminding us that at the core of Biblical faith lies a certain dialectic, fall-redemption, deathlife, law-gospel, sin-grace. In this lecture I invite your attention to one of the poles of this Biblical dialectic, the idea of $\sin$.

As far as the doctrine of sin is concerned this recent period has been one of profound challenge. Man's self-understanding has undergone radical revision in the last hundred years and in the process all manner of problems have been raised for this Christian doctrine. It is perhaps indicative of the complexity of these issues that, apart from its being treated within the compass of larger systematic projects such as those of Barth, Brunner or Tillich, one looks almost in vain during this century for a major discussion of sin. Among the many new factors to be contended with one might mention three fairly obvious ones. One is the emergence of the modern scientific view of man and his origins as expressed in the theory of biological evolution, giving rise to questions such as - What may we say of the creation and fall of man, with all its traditional implications for the idea of sin, in face of the claims of Darwinian theory? Who was Adam, and what relation, if any does he have to the race? Another new factor during this

\footnotetext{
*Delivered at a special Winter Meeting of the Tyndale Fellowship held in London, 3 January 1975.

${ }^{1}$ Cited J.R. Coates, Bible Key Words from Gerhard Kittel's Theologische Worterbuch zum Neuen Testament : Sin, Adam and Charles Black, London (1951) intro. $v$.
} 
last century has been the emergence and widespread dissemination of the ideas of Karl Marx, facing us with questions such as - What meaning and significance can we give to individual sin in the light of Marx's all-embracing socio-economic account of behaviour and values? What kind of victory over sin can we claim in face of his scathing exposure of the Church's social and political record? Then also this period has seen the rise of the whole psycho-analytical approach associated with the work of Freud, Jung and others. Hence we find ourselves being asked - What can guilt before God mean now? How does such guilt relate to alleged behavioural and character determinants in the individual's conscious and unconscious past? And this list is not exhaustive. Any one of these developments would have created problems enough. The combination of the three and their various more contemporary cousins goes a long way to explain the dearth of theological pronouncement in this area during this century, and one might be excused from entering so unsettled a field at such a time. However, there is a further factor in the contemporary scene which encourages our return to this area of Christian truth in spite of its unnerving problematics and that is a witness outwith the Church, the mood of the secular world. For this same period which has witnessed the emergence of these powerful new theoretical challenges to the traditional view of man as sinner has also seen the almost total overthrow of the easy optimism and self-confidence of the nineteenth century and its replacement by a radical and ever-deepening pessimism. And if we have learned the wisdom of reading the novels of our time as well as the theological journals and retained contact with the theatre as well as the seminar, or even if we have engaged seriously in pastoral ministry at any level of our society, we will find there adequate stimulus to grapple with this doctrine. For this encounter will surely awaken such a compassion for these desperately needy contemporaries of ours that we will long to give expression, in terms of the Biblical idea of sin, to the true character of the needs which they are so profoundly conscious of, and hence direct them to the One whose very name enshrines His claim to save His people from their sins.

In this lecture we will attempt an examination of the way theology has sought to come to terms with the idea of sin 
during this century. A general survey of the period is clearly beyond the scope of a single lecture. I will therefore confine myself to three representative theologians, expound and assess their constructions noting how they have responded to recent challenges, and seek to learn from their strengths and weaknesses.

\section{Karl Barth}

It is generally agreed that Barth's theology represents the watershed which divides modern theology from the classical liberalism of the nineteenth century. ${ }^{2}$ Such is the breadth and significance of Barth's work that it is impossible to grapple responsibly with any major Christian doctrine in this century without having to come to terms with Barth's treatment of it, and $\sin$ is no exception.

In our exposition, however, we require to begin where Barth began, in the nineteenth century, for, as James Smart reminds us -

"The theology of neo-protestantism was never for Barth, as for some of his critics, an interpretation of Christianity that he had known only in other men. It was the theology by which he himself had once lived and preached and taught."3

Whatever its particular emphases may have been, and they varied from theologian to theologian, the essence of this movement as Barth later saw it was its anthropocentricity. ${ }^{4}$ In its teaching man occupied the centre of the stage and his moral and religious experience, his social and cultural awareness, became the all-absorbing centre of attention. In an assessment of this period written in 1957 Barth formulated this fundamental mistake as he saw it, as lying in its having

\footnotetext{
${ }^{2}$ See for example H.R. Mackintosh, Types of Modern Theology, Collins, London (1937) $24: 2 \mathrm{f}$.

3 James D. Smart, The Divided Mind of Modern Theology, Westminster Press, Philadelphia (1968) 45.

${ }^{4}$ The Word of God and the Word of Man, tr. D. Horton, Hodder and Stoughton, London (1928) passim; From Rousseau to Ritschl, tr. B. Cozens and H. Hartwell, SCM; London (1959) 150-196, 306-354, 390-397; God, Grace and Gospel, tr. J.S. McNab, ed. T.F. Torrance and J.S.K. Reid, Scottish Journal of Theology Occasional Papers No. 8, Oliver and Boyd, Edinburgh (1959) 55-74.
} 
taken contemporary man too seriously in his own terms. ${ }^{5}$ As a result nineteenth century man's view of the world and his current self-understanding were uncritically adopted as the basis upon which the theologian was required to work. Barth's break with this theology is a familiar story. ${ }^{6} \mathrm{~A}$ combination of the demands of pastoral ministry particularly that of the pulpit, the ethical failure of this theology in the face of the Kaiser's war, and perhaps most of all his discovery of "the strange new world of the Bible"7 served to open Barth's eyes to the mistaken course of classical liberalism. It was not just that it was mistaken at this or that point, it was moving in a wholly wrong direction. Out of the resulting ferment emerged the Commentaries on Romans of 1919 and 1922 which represent a sustained assault upon nineteenth century religiousity and its anthropocentric preoccupation, and an attempt to recover the Godness of God, the transcendent Other at infinite qualitative distance from man who cannot focus Him in either his thinking or experience. The implications of all this for the doctrine of sin were profound. Here was a tearing apart of God and man and the opening up of a great gulf between the two. Man found himself no longer nodding religiously across at a God beside him. He now strained upwards from the depth of his need towards a God who towered threateningly over him. In a word - sin was rediscovered. $^{8}$ To make a proper assessment of Barth's view however we require to turn to his massive Church. Dogmatics left unfinished at his death in 1968. What is the understanding of sin which is expounded there?

The first comment we require to make, and this takes us to the heart of the matter as far as Barth is concerned, is that

5 "Evangelical Theology in the Nineteenth Century", God, Grace and Gospel 66f; cf. also T.F. Torrance, intro. to Theology and Church tr. L.P. Smith, SCM, London (1962) 50; and T.F. Torrance, Karl Barth : An Introduction to His Early Theology, SCM, London (1962) 83-84; T.E. Hulme, Speculations, London (1924) 10.

${ }^{6}$ God, Grace and Gospel 58; Word of God and Word of Man 28-50; James D. Smart ed., Revolutionary Theology in the Making, SCM, London (1962) 12f, 217-8; T.F. Torrance, intro. to Theology and Church 11f; E. Thurneysen, 'Zum rel. sozialen Problem' in Zwischen den Zeiten, 1927, 515; G.C. Berkouwer, The Triumph of Grace in the Theology of Karl Barth, Paternoster Press, London (1956) 45; James D. Smart, The Divided Mind of Modern Theology 60.

7 The Word of God and the Word of Man, 28.

8 The Epistle to the Romans, tr. E. Hoskyns, Oxford (1933) 167-187, 240f, 246f, 278f, 286, 362 . 
there is no distinct section or chapter entitled 'Sin' or 'Man and Sin'. Whereas earlier dogmaticians customarily treated sin in a separate section usually following upon the treatment of Revelation and God, Barth rejects this method. For him sin has no autonomy. It cannot be treated in distinction from the whole corpus of Christian truth, and in particular from the Being and Action of God in His grace. In accordance with this basic conviction the main expositions of the idea of sin occur in Volume IV of the Dogmatics, i.e. under the Doctrine of Reconciliation. Here Barth sets forth the work of Christ as Priest and King and Prophet and in the light of man's sin as pride, sloth and falsehood. Along with these sections we require to note others in earlier volumes in which he establishes some of his crucial presuppositions; II/I where he argues that grace is one of the Perfections of God; III/2 where he expounds his anthropology with its Christological base; III/3 during his discussion of providence, his important section Gott und das Nichtige where he grapples with the problem of evil in God's world. We will attempt to summarise Barth's view.

The key to Barth's understanding of sin, and indeed to his view of every Christian doctrine is his understanding of grace. For Barth God is the gracious God. Grace is His Being and essence. Hence, all of our theological statements and formulations are valid only insofar as they indicate this situation. There is no other God than this God. ${ }^{9}$ Hence there is no other world than the one created and upheld by and for this gracious God. Hence there is no other creature than the one called into being, redeemed and glorified by and for this God. Further, grace has a quite specific meaning as the covenant fulfilled in Jesus Christ. ${ }^{10}$ Grace means this concrete act and event. Sin too is known only here, a posteriori, at the point of God's dealing with it in His grace. ${ }^{11}$ The priority of grace

${ }^{9}$ Church Dogmatics, II/1, 353f; cf. also Barth's discussion p. 327ff, with Calvin, Institutes of the Christian Religion, I, 10, 2, tr. Battles, SCM, London (1961) Vol. 1. 96-97; and Barth, $C D$. III/2, 609; II $/ 1,358$.

${ }_{10 !} C D, \mathrm{I} / 2,250 ; \mathrm{II} / 1,251 ; \mathrm{III} / 2,164 ; \mathrm{III} / 3,73 ; \mathrm{IV} / 1,216 ;$ God, Grace and Gospel 4,6; The Knowledge of God and the Service of God, tr. J. Haire and I Henderson, Hodder and Stoughton (1938) 72; Credo, tr. J.S. McNab, Hodder and Stoughton, London (1936), cf. here Barth's strong criticism of the Roman Catholic view of grace, IV/1, 86-87.

${ }^{11} C D \mathrm{I} / 2,882 ; \mathrm{II} / 1,398$. 
is thus the decisive presupposition of Barth's view of sin. Over against the nineteenth century Barth seeks to move consistently from God to man. There can be no starting point in any human experience of shame or guilt or in any human reflection upon the more baleful elements of existence. Sin can only be known in the light of grace, i.e. in the light of God's action against it in Jesus Christ.

What can we say of sin from this standpoint?

1. Sin is seen to be a movement in the first instance directed against God. It is in the encounter with God that sin is disclosed and hence its being is a being in antithesis to $\mathrm{Him}$.

2. Sin is seen further to be a movement against grace. It is always a denial and refusal of grace.

3. Sin is seen as that which really does threaten the creature of God. That God must take action against it in becoming flesh and dying on Golgotha reveals the seriousness of its assault upon the creature.

4. Sin is seen as the concrete expression of a wider dimension of evil, the particularisation of a whole inimical cosmic principle, das Nichtige, which threatens the entire creation of God.

5. Sin is seen in the light of the triumphant fulfilment of the covenant in Jesus Christ as that which is vanquished and overcome in its threat to the creature. To know sin means always to know it in this relationship and hence as forgiven.

6. Sin and evil are seen in this light as distinguishable from both the creation and the creature. Both creation and creature are willed by God in His work of grace and therefore good. This goodness extends to their "shadow" or "creaturely" aspects.

7. Sin is seen as a third order of being over against the Creator and his creature.

8. Sin is seen as having its being only in antithesis to, and hence in dependence upon, the grace of the God who is Lord over all in His grace. It "is" only as that which is denied by God's affirmation, as that which is rejected by God's election, as active only under His left hand, and because of His right hand.

9. Sin is seen to be "ontologically impossible" in the light of the victory of Jesus Christ. This is the mystery of iniquity. 
10. Sin is seen over against the work of God's grace in Jesus Christ in particular forms - as pride leading to fallenness, as sloth leading to misery, as falsehood leading to condemnation.

There can be no question that Barth's position moves significantly closer to the Biblical norm than the theology of his inheritance. In his sensitivity to the fundamental misdirection of that theology and his Atlas-like attempt to lift the whole theological world and re-establish it upon fresh axes we stand in his significant debt. As far as sin is concerned his approach allows a new appreciation of its significance and hence fresh emphasis to be given to its unquestionable Biblical reality and seriousness, and that in a century when, as we observed, very acute questions were being raised for this fundamental evangelical doctrine.

There are however questions which remain, and I focus upon one central one. While by Barth's approach sin recovers significance as against the situation in the older liberalism does it recover a Biblical significance? The nineteenth century tended to lose sight of sin because it looked at man and looked at him selectively and optimistically and hence not as man coram Deo, sub specie aeternitatis, man in the light of God. But does Barth not labour under a tendency to lose sight of sin, albeit to a less serious degree, due to his looking at God in such a manner and to such a degree that man and his action and rebellion is not simply reduced to its proper, secondary place, but finally given no real place at all? In other words is Barth's theology for all its depth and breadth, its staggering erudition and yet astonishing simplicity, in the end, to some extent, a theology of reaction whereby an unbiblical anthropocentricity in the nineteenth century is replaced by an unbiblical theocentricity in the twentieth? This is a basic and serious charge. May I indicate briefly several reasons for formulating it?

We begin with Barth's terminology. Translators have encountered no little difficulty in rendering das Nichtige in English. ${ }^{12}$ Dr. Rudolph Ehrlich in the authorised translation

${ }^{12}$ CD III/3, intro. H. Hartwell, Introduction to the Theology of Karl Barth, Duckworth, London (1964) 149, prefers 'the Nihil' as does A. Cochrane in the translation of O. Weber, Introductory Report on Karl Barth's Church Dogmatics, Lutterworth Press, London (1953); cf. also G.V. Jones 'The Inimical Principle of Negation', SJT 7 (1954). 
favours 'Nothingness'. Barth's own account of it is as follows-

'Nichtige contains not only a negative but a distinctly disqualifying note. That which is nichtig is not only ineffectual, insignificant and trifling but is downright abominable yes, accursed'13

He also speaks of the "impossible possibility"14 of sin and evil, and of their "ontological impossibility".15 Barth of course is simply trying to see sin 'in the light of grace' and also to avoid dualism, the according to sin of the status of a second God, but one is bound to ask how well this kind of negative terminology reflects Biblical testimony. Again, where traditional interpretations of the idea of sin have been content to speak of the "mystery" of the relation between sin and the being of God ${ }^{16}$ Barth pushes further and attempts to give an account of it in terms of God's creative action -

'The entire context in which Nothingness is real is that of God's activity grounded in His election...God is Holy and that means that His being and activity take place in a definite opposition in a real negation both defensive and aggressive. Nothingness is that from which God separates Himself and in face of which He asserts Himself and His positive will...God elects and therefore rejects what $\mathrm{He}$ does not elect; God wills and therefore opposes what He does not will; He says Yes and therefore says No to that to which He has not said Yes...As God is Lord on the left hand as well $\mathrm{He}$ is the basis and Lord of Nothingness too... Even on his left hand the activity of God is not in vain... His rejection, opposition, negation and dismissal are powerful and effective.'17

Barth at one point depicts God as "like a human builder when he chooses one specific work and rejects and ignores another". ${ }^{18}$

13 Cited Weber, op. cit., tr. A. Cochrane, 187.

$14 C D$ III $/ 1,102 ;$ IV $/ 2,495$.

$15 C D$ III $/ 2,136,146$. cit., 217.

16 H. Bavinck, Gereformeerde Dogmatick, III, 29, cited G.C. Berkouwer, op.

${ }_{18} C D, \mathrm{III} / 3,351-352$.

$18 C D, \mathrm{III} / 1,108$. In addition to this 'going beyond' the Biblical material Barth is also charged with leaving certain Biblical elements out of account, $c f$. W. Luthi, Gott und das Böse, Zurich (1961) 261. 
Barth appears here open to the charge he levels at others, viz. of permitting the intrusion of speculative ideas into his theological explanation. ${ }^{19}$ But at a deeper level this kind of extension back into the being of God of the confrontation with sin and evil so that sin is encountered and overcome in the eternal election of God by His primal decision, His negation of the negation, raises real questions as to its reality and the significance of the encounter with it in history. ${ }^{20}$ A similar kind of question arises at other points. For instance, in his discussion of the Fall Barth seeks to distance himself from a purely mythical interpretation,,$^{21}$ and he also seeks to face the question which excessively literalistic accounts fail to observe, viz. the acute epistemological problems in attempting to speak of pre-fall realities using post-fall categories. ${ }^{22} \mathrm{~A}$ straightforward 1:1 relationship is as inappropriate here as in giving an account of the eschaton. Yet his view is not fully adequate largely because he neglects Scripture's own inspired commentary on the opening chapters of Genesis. There is a series of passages running through the Bible which relate to this area, of which Romans 5:12f is the most significant, ${ }^{23}$ and which, granted the special nature of the material, and without presupposing the precise way in which it should be related to the findings of palaeontology, require I believe the positing of an historical core to the fall account and the assertion of a significant relationship between that event and man's subsequent moral history. Barth does not reflect this in his exposition either of the Genesis passages or Romans 5 where the exegesis appears unduly controlled by his theological concern to hold creation and redemption together and to disallow Adam any independence of Christ. ${ }^{24}$ But his dehistoricising of the fall inevitably raises questions as to sin's real impingement in history in Barth's thought.

19 J. Hick, Evil and the God of Love, Macmillan, London (1966), 193; G.C.

Berkouwer, op. cit., 221-223.

20 Berkouwer, op. cit., 222.

$21 \mathrm{CD}, \mathrm{III} / 1,58$.

$22 \mathrm{CD}, \mathrm{IV} / 1,508 ; \mathrm{III} / 1,75 \mathrm{ff}$

23 Gen. 4:1; 5:4; 11:27; Deut. 32:8; I Chron. 1:1; Jb. 31:33; Lk. 3:38; I Cor. 15:22f; II Cor. 11:3; Rom. 5:12f; I Tim. 2:13-14; Jude 14; $c f$. also Ecc. 7:39; Is. 43:27; and possibly also Hos. 6:7.

24 Christ and Adàm : Man and Humanity in Romans 5 , tr. T. Smail, ed. T.F. Torrance and J.S.K. Reid, SJTh Occ. Papers No. 5, Oliver and Boyd, Edinburgh (1956) 1f; cf. J. Murray, The Epistle to the Romans, Marshall, Morgan and Scott, 
Moving on to Barth's anthropology he will not tolerate the notion of an independent fallen humanity deriving from God's creative work to which Christ comes as God's redemptive answer. This "step-wise" account of things Barth rejects along with its implied division in the works of God as between creation and redemption. ${ }^{25}$ Thus man grounded in God means man grounded in God's redemption, man grounded in Christ. Hence -

'Man's essential and original nature is to be found therefore, not in Adam but in Christ.

'The nature of the man Jesus is the key to the problem of the human. This man is man. As certainly as God's relation to sinful man is properly and primarily His relation to this man alone, and a relation to the rest of mankind only in Him and through Him, He alone is primarily and properly man.'26

Thus anthropology becomes a branch of Christology. Man's being is gathered into the being of God and understood from that ontological basis. From this perspective it becomes difficult to see what final significance can be given to man's action and history considered from the standpoint of his sin and rebellion.

A similar issue arises when we move on to consider how sin is overcome. Traditionally theology has used the terms justification, sanctification and glorification to express what it believed to be Biblical testimony concerning this. Barth's account leaves questions at each of these levels. Justification by grace is certainly affirmed but his exposition of the subjective aspects of this one work of salvation does not as adequately reflect the Biblical teaching. "Faith" loses its radical transforming character and becomes simply an "acknowledgement" of what is already true, viz. one's being

London (1961) 389; R. Bultmann, ZNW, 55 (1959) 145-165, tr. in Current Issues in New Testament Interpretation, ed. Klassen and G.F. Snyder, SCM, London (1962) 143ff; P. Lengsfeld, Koinonia : Beiträge zur Ökumenischen Spiritualität und Theologie Band 9 Adam und Christus Essen (1965) 208-216; H. Bouillard, Karl Barth, 3 Vols., Ed. Montaigne, Paris (1957), Vol. I, $51-52$.

${ }^{25} C D$ II/2, 135f; cf. G.C. Berkouwer, op. cit., 255f; also by the same author, The Work of Christ, Eerdmans, Grand Rapids (1965), chapter 2 passim.

${ }^{26}$ Christ and Adam, p.6; III/2, 43. Cf. also Barth, The Epistle to the Philippians, tr. J.W. Leitch, SCM, London (1962) 101-102. 
redeemed in Christ from all eternity. ${ }^{27}$ Certainly Scripture would give no encouragement for viewing faith as other than an "empty hand" (Barth's phrase) but it also at the same time invests faith with a cruciality which one misses in Barth's account. It appears to speak of the necessity of an encounter in history between man and the mighty Object of his faith, Jesus Christ the Lord. ${ }^{28}$ Barth has much to say about faith but one is left asking whether his commendable concern to escape the dangers of concentrating attention on the response of man to the gospel does not expose him to the danger at the other pole that the encounter of the individual with Christ in history is removed from real history to a realm of super-history where it is objectivised into an "acknowledgement" of what has been already done and is already true. ${ }^{29}$ Faith hence becomes centred in a noetic movement from a not knowing to a knowing rather than as in the New Testament where it is centred in an ontic movement from a 'not being' to a 'being'.

In his discussion of sanctification Barth manifests the same extreme objectivism. ${ }^{30}$ Sanctification has traditionally implied the progressive renewal, albeit limited and circumscribed, of the individual believer and the believing community in conformity with the likeness of Christ, and in this connection the Church has spoken of the work of the Holy Spirit. Barth speaks of the work of the Spirit here but it is important to notice what his precise function is - "His work consists in the fact that He enlightens us". ${ }^{31}$ Barth criticises Calvin at this point for restricting the work of the Holy Spirit in sanctification "to the circle of the elect". ${ }^{32}$ Calvin's approach however enables him to speak in a way which Barth cannot, but which the New Testament certainly appears to, of the "double grace" which believers receive from Christ, justification and sanctification, which latter he defines as "the cultivation of blamelessness and purity of life";3 "Une

${ }^{27} C D, \mathrm{IV} / 1,631$.

28 Mt. 11; 27f; Jn. 3:16-21,36; 5:24,40; 10:13; Acts 2:38; 16:30f; Rom. 1:16f; $3: 25 ; 4: 3 ; 5: 1 ; 8: 1 f ; 9: 30 f ; 2$ Cor. 5:17-21; Gal. 2:6; 3:6; Eph. 2:1-10; Heb. 4:3f;

1 Pet. $2: 10 ; 4: 17$ f; 1 Jn. $1: 9$.

29 J. Murray, op. cit., 385.

$30 \mathrm{CD}, \mathrm{IV} / 2,515$ and 517.

$31 \mathrm{CD}, \mathrm{IV} / 2,522$.

$32 \mathrm{CD}, \mathrm{IV} / 2,520$.

33 Institutes, 3, 11, 1. tr. Battles, Vol. I, 725. 
pureté actuelle" as he calls it in one place. ${ }^{34}$ The reason why Barth cannot reflect this is his unwillingness to allow an ontological distinction between Christians and non-Christians, and because he is so sensitive to any idea of God's being drawn into man's experience and becoming thereby in a sense man's possession and servant. This is also why Barth cannot reflect the clear Biblical testimony to the warfare and conflict in Christian experience with the evil powers. ${ }^{35}$ Once again man's encounter with sin in history appears to be objectivised away into a super-history in the being of God.

A similar problem arises in Barth's eschatological teaching. Although he explicitly disavows universalism one has to confess that the presuppositions of the doctrine are there. Barth stops short of it, not because of Biblical testimony to the contrary, but because universalism usurps the sovereign freedom of God. ${ }^{36}$ The deeper reason would appear to be that by Barth's view of man and his sin, man does not have the power to break free from God in the radical and final sense which the idea of reprobation witnesses to. In the light of grace sin is just not that serious.

Thus for all that we can learn from Barth at many points his treatment of sin is not fully satisfactory, indeed in the end it is seriously misleading. As against the unwarranted optimism of the nineteenth century Barth has pointed us back to man's plight as a sinner and to the greatness and richness of God's redemption in Christ, but in so doing he has been caught up, I believe, in a reactionary tendency which has carried him beyond the limits of Scripture and in the end tends to a dehistoricising of man's rebellion against God and to the taking of sin with insufficient seriousness.

As far as the restating of a doctrine of sin for the twentieth century is concerned Barth's anthropology with its thoroughgoing rejection of all generalised approaches to man and his commitment to theological, i.e. Christological factors, means that Marx, Freud or Darwin's questions do not come directly

34 Sermon on Gal. 2:17-18;cf. also Commentary on the Acts of the Apostles, comment on 15:9, cited R.S. Wallace, Calvin's Doctrine of the Christian Life, Oliver and Boyd, Edinburgh (1959) 23.

35 Rev. 2:9, 24; 3:9; 12:9f; 16:14, 20; 20:2f, 7f; Acts 5:3; 13:10; 19:15; 26:18; Rom. $16: 20 ; 1$ Cor. $7: 5 ; 10: 20 ; 2$ Cor. $2: 11 ; 4: 4 ; 12: 7$; Eph. 2:2; 6:12; I Thes. 2:18; 2 Thes. 2:9; I Tim. 3:6-7; 2 Tim. 2:26; Heb. 2:18; Jas. 4:7; 1 Pet. $5: 8 ;$ I Jn. $2: 12 ; 3: 8 ; 5: 19$.

${ }^{36} \mathrm{CD}, \mathrm{II} / 2,417-418 ; \mathrm{II} / 2,422$. 
into view. Where Barth however does speak to our century is in the radical character of his thought. While it would be a mistake to try to explain the rise of his theology simply in terms of the crisis of our period, there can be no doubt that in his sense of the crisis of all humanity before God and in his attempt to structure a theology on that basis, Barth does strike a contemporary note. In his way Barth has sought to provide a theological answer to the problems raised for Western culture by the fall of human reason before the onslaught of existentialism and nihilism, and the rise of anarchy and violence. ${ }^{37}$ Thus there is in Barth's doctrine in this sense a significant response to contemporary challenges.

\section{Reinhold Niebuhr}

For our second case-study in modern restatement of the idea of sin we turn from Europe to America and to a theologian who has given considerable attention to the doctrine, Reinhold Niebuhr. With Niebuhr as with Barth his biographical background throws considerable light upon the shape and development of his thought. ${ }^{38}$ A son of the manse Niebuhr attended theological seminary himself to prepare for the ministry, and went to Yale in 1913 for post-graduate study. He did not complete his course there and comments significantly "epistemology bored me . . . and frankly the other side of me came out. I desired relevance rather than scholarship". ${ }^{39}$ In 1919 he accepted the call of a small evangelical and reformed church in Detroit. His theological stance was within the American popular liberalism of the time. He refers to the "liberal and highly moralistic creed which I accepted as tanamount to the Christian faith."40 After difficult early months he began to find his feet in the ministry. He wrote in $1918-$

37 C. West, Communism and the Theologians, SCM, London (1958) 190.

38 Cf. H. Hofman, The Theology of Reinhold Niebuhr, Scribners, New York (1956) 7 ". . for Niebuhr more than for any other contemporary theologian it is important to consider what determined the starting point of his theological work in order to understand him."

${ }^{39}$ Cited J. Bingham, Courage to Change, Scribners, New York (1961) 83; also Kegley and Bretall, eds., Reinhold Niebuhr, His Religious, Social, and Political Thought, Macmillan, New York (1956) 4.

40 Kegley and Bretall, op. cit., 5; also Niebuhr, Beyond Tradgedy, New York (1938) 287; D.R. Davies, Reinhold Niebuhr, Prophet from America, Jas. Clarke, London (1940) 15; E.J. Carnell, The Theology of Reinhold Niebuhr, Eerdmans, Grand Rapids (1951) 17-21. 
'I am really beginning to like the ministry. I think since I stopped worrying so much about the intellectual problems of religion and have begun to explore some of its ethical problems there is more of a thrill in preaching. ${ }^{41}$

Detroit in the early 1900's was the ideal centre for one seeking to "explore the ethical problems of religion". The Ford company was just beginning the rapid expansion which was to make it the motor centre of the world and during his thirteen years pastorate there Niebuhr was faced at first hand with the realities of the new automated industrial pattern and forced to think through the whole range of its implication for the Christian ethic. Niebuhr's encounter with Ford in Detroit is of crucial significance for an understanding of his theological outlook. "The resulting facts (of Ford's expansion) determined my development more than any books which I may have read". ${ }^{42}$ Or, as he put it more succinctly elsewhere, "I cut my eye-teeth fighting Ford". 43

This encounter with the darker aspect of industrial capitalism aroused an understandable appreciation for Karl Marx, and his two earliest books, Does Civilisation Need Religion? ${ }^{44}$ (1928) and Moral Man and Immoral Society (1934) ${ }^{45}$ both reveal a sympathy for Marx's socio-economic critique of religion. In 1928 Niebuhr left Detroit for the Chair of Christian Ethics at Union Seminary New York where he remained until his retiral in 1960. Although certain developments can be traced in his thought over the years he remained basically loyal to the standpoint which he came to adopt during his years in Detroit. ${ }^{46}$ His primary interest therefore had been in the field of theological ethics. The primary fact for Niebuhr to which he constantly returns in his writing and thought is man-in-community, man in the immediate social and cultural relationships in which he stands. ${ }^{47}$ Whether it is the Ford

41 Leaves from the Diary of a Tamed Cynic, Meridian, New York (1929) 45.

42 Kegley and Bretall, op. cit., 5.

43 Cited, Bingham, op. cit., Kegley and Bretall,op. cit., 13.

44 Does Civilisation Need Religion?, Macmillan, New York (1927).

45 Moral Man and Immoral Society, Scribners, New York (1932).

46 For attempts to trace a development in Niebuhr's thought cf. Paul Lehman in Kegley and Bretall, op. cit., 252ff; C. West, op. cit., $140 \mathrm{ff}$.

Moral Man and Immoral Society, 257-277; The Self and the Dramas of History, Scribners, New York (1955) 46f; Children of Light and the Children of Darkness, Nisbet, New York (1945) 35f; An Interpretation of Christian Ethics, SCM, London (1936) $149 \mathrm{f}$. 
workers in the 1920's or the urban proletariat of the 1930's or the post war situation of the 1940's and 50's the basic reality, the ultimate datum is man in his immediate social situation; and in this he stands sharply over against Barth ${ }^{48}$ for whom primary reality is the Word of God, God in His act of grace in Jesus Christ. We can characterise Niebuhr's approach as dynamic realism. It is realist as against the idealism of the social gospel movement in its concern to see man as he is rather than as he might conceivably become. ${ }^{49}$ It will not mitigate to any extent the facts of human sin and perversity. It is dynamic in its concern to see man in the flux and movement of his social relationships. Niebuhr begins his anthropology with an assertion of the dualistic nature of man -

'The obvious fact is that man is a child of nature, subject to its vicissitudes, compelled by its necessities, driven by its impulses, and confined within the brevity of the years which nature permits its varied organic forms. The other less obvious fact is that man is a spirit who stems outside of nature, life, himself, his reason, and the world.'so

Man is "in and yet above nature ... He stands at the juncture of nature and spirit and is involved in both freedom and necessity." 51 Man, that is, is a dualistic being, a part of the natural order and yet transcending it. This self-transcendence in Man Niebuhr sees confirmed by the tensions and unresolved problems of modern anthropologies. These problems arise from the fact that they -

'Lack a principle of interpretation which can do justice to both the height of human self-transcendence and the organic unity between the spirit of man and his physical life. ${ }^{52}$

48 This divergence from Barth came into the open in a series of articles in the Christian Century which appeared following the World Council of Churches meetings in Amsterdam in 1948. Cf. Christian Century, Vol. 55, issues of October 27 and December 8, 1948; Vol. 56, issues of February 16 and 23, 1949.

49 'Realist' is a notoriously difficult word to pin down. M. Thelen in Man as Sinner in Contemporary American Realist Theology, OUP, London (1946) 7 relates the term as used by Niebuhr to "realism with regard to human nature".

50 The Nature and Destiny of Man: Volume I Human Nature, Scribners, New York (1941) 3-4.

51 Ibid., 190 and 193.

52 Ibid., 132. 
These citations are taken from Niebuhr's Gifford lectures, The Nature and Destiny of Man and a cursory reading of his exposition might well incline one to the view that Niebuhr's dualistic view of man is based simply on observation from experience. As his argument unfolds however it becomes evident that his justification of the view is based upon revelation and Christology in particular. The final sanction of his anthropology is the person of Jesus and the agape disclosed in his self-sacrifice on the cross -

'Christ as the norm of human nature defines the final perfection of man in history. This perfection is not so much the sum total of various virtues or an absence of transgression of various laws; it is the perfection of sacrificial love ... The perfection of agape as symbolised in the cross can neither be simply reduced to the limits of history nor yet dismissed as irrelevant because it transcends history. It transcends history because history transcends itself. It is the final norm of a human nature which has no final norm in history because it is not contained in history.' ${ }^{53}$

It is important to notice the term 'symbol' which Niebuhr uses here. ${ }^{54}$ Jesus Christ symbolises the nature of man. In distinction from Barth, however, he is not the determination of man. The ontological grounding of the human does not lie in the manhood of Jesus but in man's being as the creature of God made in His image.

Against this anthropological background Niebuhr comes immediately to speak of man's sin. We have referred to Niebuhr's break with nineteenth century idealism and at no point is the break sharper than here. One writer has attempted an exposition of Niebuhr's entire thought from the standpoint of his doctrine of sin and Emil Brunner assures us that "this presentation has met with complete approval from Niebuhr

53 The Nature and Destiny of Man: Volume II, Human Destiny, Scribners, New York (1943) 71 and 78; Beyond Tragedy, 19-20; $c f$. also G. Vignaux, $L a$ Theologie de L'Histoire chez Reinhold Niebuhr, Delachaux \& Niestle, Paris (1957) $89 \mathrm{f}$.

54 Niebuhr makes frequent use of the idea of 'symbol' and the closely related notion 'my th', Beyond Tragedy, 4-6; Interpretation of Christian Ethics 36; Human Destiny 4,299; Faith and History, Scribners, New York (1949) 37; Christian Realism and Political Problems, Faber, Lond on (1953) 180; T. Minnema, art. 'Reinhold Niebuhr' in Creative Minds in Contemporary Theology, Eerdmans, Grand Rapids (1966) 398-401. 
himself". 55 Niebuhr takes his starting point (granted his premises as above) with Ritschl's reference to "the contradiction in which man finds himself". ${ }^{56}$ This contradiction already referred to in terms of man's capacity for self-transcendence is also the occasion of human sin -

'Sin lies at the juncture of spirit and nature in the sense that the peculiar and unique characteristic of human spirituality in both its good and evil tendencies can be understood only by analysing the paradoxical relation of freedom and necessity, of finiteness and the yearning for the eternal in man.' 57

Hence if we ask what then is sin? we can reply -

'Sin is the unwillingness of man to acknowledge his creatureliness and dependence upon God and his effort to make his own life independent and secure.' 58

We observe the close relation in this account between man's sinfulness on the one hand, and his finiteness and creatureliness on the other. "Man is mortal, that is his fate; man pretends not to be mortal, that is his sin." 59 Niebuhr explores the idea of $\sin$ in answer to two questions. First, why does man sin? - to which he gives the orthodox answer - because of temptation..$^{60}$ Second, how does sin present itself to man; what is the state of mind in which sin appears as such? This Niebuhr answers is anxiety -

'Man being free and bound, both limited and limitless, is anxious ... Anxiety is the inevitable concomitant of the paradox of freedom and finiteness in which man is involved. Anxiety is the internal precondition of $\sin .{ }^{61}$

In his exposition at this point Niebuhr leans heavily on Kierkegaard, particularly his Concept of Dread ${ }^{62}$ which

55 Emil Brunner, art. 'Some remarks on Reinhold Niebuhr's work as a Christian thinker' in Kegley and Bretall, op. cit., 31 .

56 Human Nature, 190.

57 An Interpretation of Christian Ethics, 87.

58 Human Nature, 147; also Human Destiny, 226 fn.; Faith and History 106f; Children of Light and the Children of Darkness, 21;Beyond Tragedy, 11 and 28.

59 Beyond Tragedy, 128.

60 Human Nature, 192f; An Interpretation of Christian Ethics, 83-84.

61 Human Nature, 194-195; also Human Destiny, 76; Beyond Tragedy, 98.

62 Concept of Dread, tr. W. Lowrie, Princeton University Press (1944). The de- 
argues similarly for the importance of the category of anxiety in an account of sin. Finally Niebuhr expounds the forms of sin and follows familiar paths in affirming them to be pride and sensuality. ${ }^{63}$ True to his social vision his exposition of the forms of pride gives considerable place to the pride of nations and communities, ${ }^{64}$ and true to his suspicion of all religious pretensions he sees the highest and most sinister form of pride as spiritual pride -

'Religion is not simply as is generally supposed an inherently virtuous human quest for God. It is merely the final battleground between God and man's self esteem. ${ }^{55}$

As far as the question of the relationship of Niebuhr's.idea of sin to twentieth century secular anthropologies and the questions they raise is concerned, we need to note for one thing Niebuhr's existentialist element. Some critics go so far as to see him as a straightforward extentialist, but I personally find that a somewhat forced characterisation. Certainly there is borrowing from Kierkegaard as we noted. One might also mention in this connection his removal of the fall and justitia originalis from objective history, in deference to naturalistic accounts of human origins, and his understanding of them wholly in terms of subjective experience. ${ }^{66}$ But Niebuhr never loses his sense of man's essential corporateness and hence the individualism of Kierkegaard and other existential writers has no appeal. He also never lost a robust confidence in human reason so that the irrationalism of existentialism is also unacceptable. ${ }^{67}$ Niebuhr gives a fair degree of attention

pendence is very close indeed. Whole sentences in Niebuhr's account could have come straight from there. $C f$. for example, 'Anxiety is the internal precondition of sin' (Human Nature, 194-195) with 'Dread is the psychological state which preceeds sin' (Concept of Dread, 82). On Niebuhr's relationship to Kierkegaard see J. Kroner, art. 'The historical roots of Niebuhr's thought' in Kegley and Bretall, op. cit., 182183.

63 Human Nature, 198; Beyond Tragedy, 28.

64 Human Nature, 221f; Moral Man and Immoral Society, passim.

65 Human Nature, 213.

66 Human Nature, 281-318; 191f; Interpretation of Christian Ethics, 35f; 82f; Man's Nature and His Communities, Bles, London (1966) 15-16; Beyond Tragedy, 10f $;$ Faith and History, 37; Christian Realism and Political Problems, 186.

67 Cf. essay "Coherence, Incoherence and Christian Faith" in Christian Realism and Political Problems, $165 \mathrm{ff}$. 
to Freud and this in its way reflects something of the tremendous impact which psychology of religion made on American theology in the early part of this century. ${ }^{68}$. However, Niebuhr's references to psycho-analysis are mostly critical. ${ }^{69}$ Niebuhr is too committed to the real in terms of social and political structures to be over impressed by an approach to reality via the sub-conscious. Marx however certainly exercised a significant influence. ${ }^{70} \mathrm{He}$ provided Niebuhr with a key to interpret his situation in Detroit during his formative years and also helped to kindle Niebuhr's inherent suspicion of high-blown ideological views, whether theological or otherwise. But there is no evidence that Marxism as a total interpretation of reality posed itself as a real alternative for Niebuhr. He shows a clear sensitivity to the ideological pretensions of Marxism itself and of the continued presence in communist society of the will to power in the clash of competing factions. ${ }^{71}$ As a critical tool however he found it of value in exposing the idealism of his earlier liberal convictions and their fellow-travellers of more recent decades.

There certainly are positive values in Niebuhr's restatement of the idea of sin. To read him after absorbing something of the moral and political idealism of last century is like taking a cold shower on a humid dreamy afternoon. Reality obtrudes! His unwearying witness to the social dimension of sin is something which we cannot ignore even if we are persuaded of a clear individualism at the core of the Biblical doctrines of sin and redemption. The recent Lausanne Covenant ${ }^{72}$ would appear to indicate a new recognition of this element by evangelicals even though there is still much work to be done in seemng how the two dimensions relate Biblically. Finally one would refer to Niebuhr's exposure of the dangers of sinful

68 Smith, Handy, Loetscher, (eds.) American Christianity, Vol. II, Scribner, New York (1963), 429. Cf. Walter Horton, A Psychological Approach to Theology, Harper, New York (1931); William James, Varieties of Religious Experience, Longmans, London (1928); G.A. Coe, Psychology of Religion, Chicago U.P. (1916).

${ }^{69}$ Human Nature, 26 ; 36-38; 44f; 54-56.

70 For a full documentation of this influence see Charles West, Communism and the Theologians, 117-176.

${ }^{71}$ Human Nature, 46ff; 208ff; The Children of Light and the Children of Darkness, 79f; Christian Realism and Political Problems, $41 \mathrm{ff}$.

${ }^{72}$ Cf. Let the Earth Hear His Voice: a Comprehensive Volume of World Evangelisation, ed. J.D. Douglas, Worldwide Publications, Minneapolis (1975) 4f; $c f$. also $116 \mathrm{f}$; $319 \mathrm{f}$. 
self-delusion even at the highest levels of human sanctity.

Again questions remain, and as with Barth we light upon one central issue - Niebuhr's pessimism. There is a heaviness and burden to so much of his writing which, while an advance on earlier facile optimisms, is out of harmony with the full Biblical perspective. Niebuhr exposes sin and confronts us with man the sinner, but he has little to offer by way of solution and we listen almost in vain to hear a reflection of the New Testament's note of hope and victory in face of sin and evil. Theologically this pessimism appears traceable to the very close relation between sin and finitude in his thought so that sin attains a certain inevitability. ${ }^{73}$. One is reminded of the limerick composed by Archbishop Temple after Niebuhr had addressed a conference at Swanwick -

"At Swanwick when Niebuhr had quit it,

Said a young man at last I have hit it -

Since I cannot do right

I must find out tonight

The best sin to commit - and commit it!"74

Niebuhr defends this sense of sin's inevitability on grounds of its being orthodox Paulinism ${ }^{75}$ but there is no balancing reflection in Niebuhr of Paul's exultant hope and throbbing sense of triumph over sin in the person and work of Jesus Christ. The sense of the moral irrelevance of the Christian faith to the problems of Detroit and the urban proletariat in particular, and Marx's scathing exposure of the political indiscretions of Christendom are no doubt also contributory factors to this. Another is his radical understanding of justification by grace. The fact that man's only hope of justification before God lies wholly outside of himself in the life and death of Another implies a final judgement upon all man's efforts to please God - his good as well as his evil -

Cf. Interpretation of Christian Ethics, 95 'If finiteness cannot be without guilt because it is mixed with freedom and stands under ideal possibilities, it cannot be without sin (in the more exact sense of the term) because man makes pretensions of being absolute in his finiteness'. Also Beyond Tragedy, 155f; Man Nature and His Communities, 81f; West, op. cit., 174.

${ }_{75}$ Cited J. Bingham, Courage to Change, Scribners, New York (1961) 140.

75 Human Nature, 264. 
"The Pauline doctrine really contains the whole Christian conception of God's relation to human history. It recognises the sinful corruption in human life on every level of goodness. It knows that the pride of sin is greatest when men claim to have conquered sin completely."76

Still another factor is Niebuhr's standard of judgement for human behaviour. It is a corporate standard, the law of love. ${ }^{77}$ Niebuhr cannot rest content with the holy man, he seeks the holy society, where obedience to God is not simply a matter of individual attitudes and actions but of perfected relationships. By this standard the goal is at a considerably greater remove and the possibilities of the overcoming of sin recede significantly as compared with an individualised view of man's goal. Granted all this, however, Niebuhr's exposition is not adequate. As Barth pointed out there is missing in it a whole dimension "... the Holy Spirit, the sanctification, the Kingdom, the congregation, and all these not as principles ... but as the indication of events, of concrete once-for-all, unique, divine actions, of the majestic mysteries of God that cannot be resolved into any pragmatism". ${ }^{78}$ The loss of the Holy Spirit is a particularly serious lacuna. Perhaps we can focus this by noting Niebuhr's exposition of Galations $2: 20$. He takes the opening phrase "I have been crucified with Christ" as an instance of the apostle "interpreting the destruction of the old life and the birth of the new in the symbol of the death and resurrection of Christ". But this

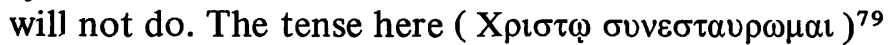
perfect (passive) indicates that Paul is speaking of the mysterious and yet glorious reality of the union of the Christian with Christ in the event of His death and resurrection. Being a Christian by this statement is not simply a matter of being involved in some kind of moral renewal symbolised in the death and resurrection of Christ, but to have actually been ingrafted into the one death and resurrection of the Lord with

${ }^{76}$ Human Destiny, 108; $c f$. also, ibid., 153.

77 Human Nature, 297f; Human Destiny, 85; 253; An Interpretation of Christian Ethics, 114-115; 123; Paul Ramsey, in Kegley and Bretall, op. cit., 86; C. West ${ }_{78}$ op. cit., 154.

78 Article 'Anglo-Saxon Vs. Continental Theology', Christian Century, February 16 th $1949,234$.

Human Destiny, 112. 
all its shattering ontological implications. It is this fact which Paul (in Romans 6) links to Christian baptism which allows him his vibrant optimism even in the face of the undeniable fact of the continuance of $\sin$ in the believer's life. This same pessimism is reflected in Niebuhr's eschatological expectation which is severly circumscribed. Perhaps the ultimate root of all this lies in Niebuhr's Christology. Christ illustrates the human predicament and points to its goal, the cross stands in Niebuhr's phrase "on the edge of History". 80 But Christ and his cross do not really enter history. They leave man were he was before. His situation is clarified but not essentially changed. We are left, in one critic's phrase -

'perpetually in the twilight position of standing under the cross looking toward the resurrection" ... the Cross and the Man on it remind the reader more strongly of the ideal state of human relations - that of selfless love poured out for others - than of the full person of the Son of God.' 81

Thus while Niebuhr's restatement of the idea of sin moves us forward from the nineteenth century and while it seeks at points to relate itself helpfully to the anthropologies of the twentieth it falls short of our requirement. It does so, I believe, because its realism is in the final analysis a human realism whereby man's problem reduces in the end to his inhumanity to his fellow man, his pride, and selfishness, and will to power. But to see man thus is to miss a whole dimension, man coram Deo. The final seriousness of $\sin$ is precisely that it is committed before God and that it rises up against Him and draws forth and encounters a divine resistance, His Holy wrath. Man's profoundest need accordingly is not a new social selflessness, though that is ever to be sought and longed for, but a reconciliation with God. It is only when that need is focused that sin's real terror is uncovered, and that the full glory and wonder of God's gracious salvation can be confessed and honoured. Niebuhr stops short of the full terms of man's need, and hence, paradoxically as it may seem, cannot direct us to the fulness of God's answer in Jesus Christ.

80 Ibid., 71; Faith and History, $157 \mathrm{ff}$.
81 West, op. cit., 151 . 


\section{Norman Pittenger}

For our third and final examination of the way twentieth century theology has responded to the challenge of restating the doctrine of sin we look again across the Atlantic to the Canadian-American theologian Norman Pittenger. Pittenger's inherited theological outlook may be gauged from a description of the college in which he trained for the Christian ministry "an Anglican theological school of tractarian background and of Anglo-Catholic sympathies." 82 After several years in pastoral ministry he was called in 1935 to theological teaching at General Theological Seminary New York where he became Professor of Apologetics in 1951. He retired in 1966 and moved to this country to become Senior Resident at King's College, Cambridge, a post he currently holds. With the passage of time Pittenger became increasingly attracted to the movement known as process theology and it is as a representative of that school, and as indicating the view of sin which it attains, that we examine him now.

The historical roots of process theology lie in the philosophers of emergent evolution of the early decades of the century, (C. Lloyd-Morgan, Samuel Alexander and Gen. Jan Smuts.) ${ }^{83}$ In America the important name is that of A.N. Whitehead the Cambridge mathematician who became Professor of Philosophy in Harvard in the mid-twenties. ${ }^{84}$ I will attempt a brief characterisation of the process approach, indicate the way its anthropology develops in Pittenger's case, and then expound and assess his view of sin.

The key to process thought lies in its concentration on dynamic becoming as against static being. True being is seen as being-in-movement, involved and bound up inextricably in a process of change and development.

'Process theologians are sure that modern man is right in seeing himself as part of a changing, moving, living, active

82 The Last Things in Process Perspective, Epworth, London (1970).

${ }^{83}$ Cf. C. Lloyd-Morgan, Emergent Evolution: Life, Mind and Spirit, Williams and Norgate, London (1923); Samuel Alexander, Space, Time and Deity, Humanities Press, Atlantic Highlands, NJ (1950); Jan Smuts, Holism and Evolution, Macmillan, London (1928).

${ }^{84}$ Cf. A.N. Whitehead, Process and Reality, CUP (1929); Adventures of Ideas, CUP (1947); Religion in the Making, CUP (1927). 
world in which we do not have to do with inert substances but with dynamic processes, not so much with things as with events.' 85

The universe at its core is not abstraction but action, creativity, in constant process of development. This picture of reality which is drawn from modern scientific enquiry is extended teleologically in that reality is pictured as moving forward to a goal, so that there emerge at points new and higher levels of being. Process theology is of course not content with a merely naturalistic account of the universe and speaks of the activity of God in, with, and under the processive movement. The crucial question, however, is how precisely God relates to the world so viewed. Pittenger expresses it thus -

' $\mathrm{He}$ is not the world, since $\mathrm{He}$ is the supreme Creative

Reality to whom all wisdom, goodness and power ultimately belong; on the other hand he is 'in' the world, or better, the world is 'in' him since his wisdom, goodness and power are ultimately continually operative through the created order. $\mathrm{He}$ is ever bringing potentiality to actuality, moving the world by his love, even more than by his power, to realise more fully the divine intention which is its basic meaning. And in so doing God is himself affected by the creation in which he works; he is not aloof, not utterly unchanging and unchangeable being. Thus the conception of God which emerges is one in which there is actual divine self-realisation through divine self-expression and the response which it secures. ${ }^{86}$

Thus there are two distinguishable elements in God - his socalled primordial nature which Whitehead defines as "the unlimited conceptual realisation of the absolute wealth of potentiality";87 and his "consequent nature which originates with physical experience derived from the temporal world and then acquires integration with the primordial side."88 By this dipolar view process theologians seek to speak meaningfully of God's involvement with the world, to turn the edge of the problems which arise for any attempt to relate

\footnotetext{
85 God in Process, SCM, London (1967) 98-99.

86 The Word Incarnate, Nisbet, London (1959) 147.

87 Process and Reality, 486

88 Ibid., 489.
} 
finite being to its infinite ground, and yet avoid paying the price for this in terms of a finite God. The fundamental theological conviction which Pittenger believes secured by the process view is the nature of God as love. ${ }^{89}$ Since love means by definition relationship, the sharing of experience, response in giving and receiving, God's being as love implies and is guaranteed in his involvement in and His contingency upon, the becoming of the universe.

Man as understood from this standpoint is no abstraction, the participant in some universal human nature. He is "man on the move", man in process of becoming, man on the way to the realisation of his subjective aim, man on the way to self-fulfilment in love. ${ }^{90}$ Man can never be isolated from his fellows or from his total environment, or from the influence of his past experience, or even from his future hopes and dreams. Human being is in this full sense always societal being. ${ }^{91}$ A man is simply the momentary concretising of all that has gone in the past to make him what he is, of all that presses upon him and surrounds him in the present, and all that he may become. To use a Whiteheadean phrase he is a "routing of occasions". In developing his anthropology Pittenger draws upon three further elements - existentialism in its stress on engagement and decision as determinative of authenticity and its rejection of theoretical objectivity as a possible way of understanding existence, ${ }^{92}$ the modern understanding of history which views it as "essentially a living out of the past in the present" rather than a bare recitation of past events, $;^{93}$ and finally depth-psychology as associated with the names of Freud and Jung which teaches us that "in deep human interrelationship and in mutual acceptance our lives are made whole".94 As far as this third factor is concerned it is significant that Pittenger is prepared to concede that this psychology has rendered irrelevant the "older judgmental attitudes" in moral matters and brought about a rejection of

89 The Word Incarnate, 147-148.

90 Christology Reconsidered, SCM, London (1970) 49-50.

91 Ibid., $47 \mathrm{ff}$.

92 The Word Incarnate, 156-160.

93 Ibid., 160-162.

94 God in Process, 104; cf. also Process Thought and Christian Faith, Nisbet, London (1968) 89-93. 
the "role of punitive justice and retribution".95 Pittenger's anthropology has two motifs. First there is the dependence motif. God as creator means simply and directly that man is a dependent being. ${ }^{96}$ Pittenger trenchantly disavows any historical element in the creation narratives in Genesis. It is all myth; it speaks "not about an event that happened in the distant past but about a fact that is true today".97 But man is also man on the move, ${ }^{98}$ man in process of becoming. He is an "unfulfilled capacity".99 Involved as he is in life's ongoing, emerging process he is summoned to realise his "subjective aim" which is his self-actualisation. ${ }^{100}$ This brings us to Pittenger's second and central motif, man is created to be a lover; his self-fulfilment is hence a self-fulfilment in love. This Pittenger describes as "the central truth about man; that he is created to be and is a lover".101

'Man's dominant quality is love. Of this I am convinced; and that not only on Christian grounds but because of the extraordinary way in which psychological study, not least in Freud with his stress on the libido as the fundamental drive in human life, has demonstrated the fact. The genuinely integrating factor in human experience is the capacity to give love and to be loved.'102

Pittenger's doctrine of sin is worked out against this anthropology. Man as we have seen is man on the move, a processive being moving within the total nexus of created factors towards his self-realisation. Sin is accordingly the frustration or deflection of this movement. It is "distortion or deviation of aim". ${ }^{103}$

'Sin consists in man's failure by free decision whether his own or that of the society in which he shares to become really what in possibility he is made for.'104

95 Process Thought and Christian Faith, 89 and 93.

96 The Christian Understanding of Human Nature, Nisbet, London (1964) 21-22.

97 Ibid., 22; also God in Process, 54.

98 Christology Reconsidered, 46.

99 Christian Understanding of Human Nature, 25, 31.

${ }_{100}$ Christology Reconsidered, $47 \mathrm{f}$.

101 Time For Consent, SCM, London (1970) 45.

102 Ibid., 44; Love Looks Deep, Mowbray, London (1969); Love is the Clue, Mowbray, London (1967); Goodness Distorted, Mowbray, London (1970);

Christology Reconsidered, 50; God in Process, 103-104.

103 Christology Reconsidered, 51.

104 Goodness Distorted, 102; also Time for Consent, 57; Process Thought and Christian Faith, 63-64. 
At times Pittenger expounds this deviation in aim in fairly traditional terms as man's self-deifying attempt to deny his essential dependence, ${ }^{105}$ however his more characteristic form is in terms of his primary anthropological category, man as an unfulfilled lover. Hence sin is -

'the failure ... (by free human decision) to move in the right direction outwardly towards ones fellows, forward along the path of true self-realisation in community, inwardly in actualising one's own possibility, and hence towards God who energises in human life to creat love and nourish love-in-action. Thus sin is violation of love.' ${ }^{106}$

It will be noted that this account affords no place for sin as the breach of divine law. The omission is not accidental. The whole notion of God as a moral Lord requiring obedience to specific commands is anathema. "God is not the great moralist but the great lover". ${ }^{107}$

Pittenger's stress upon the societary nature of existence and his desire to understand sin from this position raises the question of the degree to which one may speak meaningfully of individual responsibility. He seeks to retain the place of responsibility though he does acknowledge that much of what goes to make up sin cannot be laid to the door of the individual -

'The frustration of man as lover is not in itself a sinful state although it is not what God wants for man it might be called a state that is objectively wrong ... man's frustration is to a large degree the result of his being a finite creature who in his finitude is not able to be or to do all that he has it in him to be or do. ${ }^{108}$

Pittenger however wishes to stop short of a fully deterministic account -

'we cannot claim that we are not at all responsible; we cannot claim that 'we were made that way'. We were not made

105 The Christian Understanding of Human Nature, 96.

106 Christology Reconsidered, 51-52; Time for Consent, 55f; Goodness Distorted, 99; Love is the Clue, 47.

107 Time for Consent, 58-59; Goodness Distorted, 100f; Christology Reconsidered, 51.

108 The Christian Understanding of Human Nature, 95; Time for Consent, 56; also Goodness Distorted, 99. 
that way; that is not the truth about us . . . to fall back on the childish plea 'I can't help it' is to deny our manhood.'109

There are two further elements which we require to draw into the open. First, by this understanding of sin in terms of wrong attitudes and relationships Pittenger deliberately avoids what he regards as the fundamental error of reifying sin. It is not a 'thing', 110 an entity which people have or do not have. Second, by his approach Pittenger avoids the related danger as he sees it of a deeply pessimistic view of man as sinner. He speaks strongly against any notion of 'radical evil' which he thinks more akin to Manicheism than Christianity. ${ }^{111}$ Any notion of "total depravity" he thinks blasphemous since it impugns either the goodness of God in his work or creation, or the Lordship of God within His creation. ${ }^{112}$

The value of Pittenger's process approach to sin appears to lie in its reminder that human existence does have a dynamic element. We may well be unable to adopt Pittenger's framework and find him at times trite and unconvincing, but he does at very least help us to be on our guard against excessively abstractive, theoretical approaches to the doctrine. Further, in his teleological stress on man moving to a goal in God's purpose, man as an "unfulfilled capacity" there would appear to be a category which could be fruitfully accommodated in a properly Biblical anthropology in terms of man's destiny in conformity to the stature of Christ, the Second Adam.

Very real questions however remain and following our previous practice we take up one basic one - is sin by this view not domesticated almost out of recognition. The question arises from the very centre of process thought, its understanding of God. Two comments seem in order in response to this. Firstly, there would appear very great difficulty in conceiving a being concerning whom we are required to assert simultaneously his infinity and his finitude, his absolute necessity and his dependence, his eternity and his temporality. ${ }^{113}$

109 The Christian Understanding of Human Nature, 103; cf. F.R. Tennent, The Concept of Sin, CUP (1912) 272.

110 Time for Consent, $53 \mathrm{f}$.

$111 \mathrm{Cf}$. the "over pessimism of neo-orthodox theology", Word Incarnate, 208. 103 i 13

112 Ibid., 210; cf. also The Christian Understanding of Human Nature, 102-

113 H.P. Owen, Concepts of Deity, Macmillan, London (1971) 82-89. 
Secondly, the claim that God cannot be thought of as love unless he enters as a partner in a developing experience of sharing and growth appears a piece of gratuitous anthropomorphism. ${ }^{114}$ In the end the process God is a being significantly lower and inferior to the God of the Bible, the God over all, Who is blessed forever (and by the same token the created order appears to be elevated to some kind of independent divinity alongside God). When this scheme is adopted sin at a stroke is shorn of its distinctive Biblical seriousness, for the God against whom sin stands is not the Almighty Lord, the Holy One of the Scriptures. Further, since He and all things, including our personal histories, are caught up in the processive movement, fixed and final criteria become difficult to conceive; everything is relativised. Again by this sin's seriousness is qualified for its seriousness arises precisely from the fact that it stands against the finality of the Holy character of God, that it resists and moves against the way things are, and ever shall be, world without end.

Closely related to this problem is another one, viz. that the process view cannot, I believe, really cope with Biblical faith in its commitment to history. Process theologians in fact claim to be able to take history more seriously than traditional theological approaches. However, at a crucial point process thought appears unable to meet the requirement, i.e. the point at which particular events in the Biblical history become determinative for the entire process. Thus, for example, the Biblical witness to God's act of creation at the beginning which has found traditional expression in the notion of creatio ex nihilo cannot be properly reflected in Pittenger's scheme, not least because God is not Lord of creation in the sense this implies. The fall as determinative of future history in some significant way, to say nothing of a justitia originalis preceding it are also not able to be confessed within this framework. A written law of God as the specifying of His changeless requirements and as expressions of His loving will for His children is also untenable; which partly explains Pittenger's preparedness to countenance and even encourage relationships in the sexual sphere which contradict explicit Biblical commands. The full New Testament witness to the uniqueness and finality of Jesus Christ is another tension

114 Ibid., 85. 
point, and the cross as an historical event through which the relationship between God and sinners is radically and eternally altered also cannot find a place. One is not surprised to learn that Pittenger espouses an Abelardian view of the atonement. Nor, and here we come to our special concern, can this view accommodate my act of sin as an event by which my eternal destiny is determinatively affected.

Many other issues call for discussion in Pittenger's restatement of the idea of sin but sufficient to have demonstrated that within the process conceptuality sin must always be domesticated and appear stripped of the terrible seriousness with which it appears in Scripture.

\section{Conclusion}

In the course of this lecture we have attempted a brief examination of certain twentieth century theologians' attempts to restate the doctrine of $\sin$ in the face of the many problems raised for the doctrine in this period. Barth's attempt to circumvent many of these problems by his radical appeal to revelation and Christology allows him to reflect something of the essential Biblical witness, but the value of his approach is finally moderated by his reactionary tendency to his inherited nineteenth century creed with the result that sin in the end does not attain a proper Biblical seriousness. Niebuhr takes his stance on the borderland between the gospel and the world and seeks to construct a doctrine of sin in closest relationship to immediate human realities, particularly social ones, and hence is more open than Barth to the influence of secular anthropologies. While escaping some of Barth's more heavily theological problems he encounters others of his own which arise from his hesitation to view sin theologically. Thus he too fails to see sin in its full Biblical terms and is also inhibited from expounding the fulness of God's answer in Christ. Pittenger's approach via the process theological framework which is taken to a large extent from a scientific world-view is indicative of a greater willingness than either Barth or Niebuhr to restructure the doctrine of sin in the light of secular approaches, but in the end he pays the price of taking modern man too seriously in his own terms and so encounters very great difficulty in seeing either sin or its solution in properly Biblical terms. 
Thus none of the theologians under review have enunciated a twentieth century view of sin which is also adequately Biblical. Yet the attempt to structure such must surely be made. The prodigal will not be returned to the homeland merely by shouting our traditional cliches from the security of the Father's house. We need to go to the far country and address him there in the context of his self-understanding and experience. Having come to him, on the other hand, our responsibility is not discharged by helping him to come to terms with the far country, or by convincing him that the swine-husks are really an adequate diet for his empty, aching belly. We have to make him see his situation in all its rebellious folly, yes to the point of his catching the stink of the pig-sty in his nostrils; but we will speak too of the homeland, and delight to assure him of the sheer, staggering miracle of a Father's mercy and all-forgiving grace; and of a renewed sonship, and a new dignity and destiny in the family circle of God.

All of which leads us to a further question - how do we do that? How may we structure a doctrine of sin which is both fully Biblical and addressed to today's prodigals in today's far country. But that is the task of another lecture, and I suspect of another lecturer. Yet it is I submit an urgent and necessary task, for the sake of these desperately needy contemporaries of ours, and even more, for the sake and honour of the blessed God who waits to be glorified in their salvation. 